\title{
SEMINAR ON THEOLOGY AND THE SOCIAL SCIENCES
}

There were five discussion leaders in the seminar. Each read a brief paper which was immediately discussed. On the second day there was general discussion without any formal presentation.

The presenters were: Brian O'Connell, C.M. (St. John's University, New York); Kathy E. Ferguson, (Siena College, New York); Mary I. Buckley, (St. John's University, New York); Joseph Komonchak, (The Catholic University of America, Washington, D.C.); Paul Surlis, (St. John's University, New York), who also served as moderator.

Brian O'Connell offered insights from applied areas of sociology, especially demographic and labor market studies. Particular emphasis was given to background issues for a theological contribution to the bishops' pastoral on the economy. His focus was on issues new to the theologysocial science dialogue, rather than on issues well known to the participants.

The outstanding new realization in U.S. demographic studies is that $30 \%$ of the post World War II baby-boom generation are not having children of their own. The corresponding percentage for the 1930's birth cohort was $10 \%$. The percentage of people never marrying has risen similarly. A recent study shows $33 \%$ of young women and $19 \%$ of young men are not "greatly bothered" by the thought of never marrying. Other studies showing people making choices about family and career at age 30 that they had not anticipated five or ten years earlier. These facts provide a starting point for theological analysis of their explanations and implications. Theologians might pay attention to the growing volume of studies on the connection between population no-growth and the economy.

Many asked O'Connell about Greeley's optimistic picture of the "Young Catholic Family," showing that in 56\% of the cases, both spouses reported being "very satisfied" with their marriages. O'Connell remarked that the methodology was sound, except that the divorce rates for the sample are not given and the statistics reflect only the intact marriages. But the satisfaction is real for many people. This does not contradict the fact divorce rates are high. New opportunities for deeper relationships are accompanied by new risks and vulnerabilities.

Mexico provides a good example of a Third World labor market. Just to prevent worse poverty, the non-agricultural workforce has to triple from 13 million in 1979 to 39 million in 2000 . A job growth rate faster than the U.S. ever had is required. It is not the task of theologians to design the economy, but theology should not fail to critique programs or movements lacking job creation plans.

In the U.S., 32 million white-collar jobs were created since 1960, and only 2 million blue-collar jobs. Two-thirds of the new jobs pay less than the mean industrial wage (now $\$ 17,500$ ). By 1990, half of all jobs will be at 
electronic work stations. There is much material for theological analysis here, particularly on the fate of new entrants and minorities in this labor market. The percentage of young adults failing to reach the status level of their parents is increasing, a fact with many implications. The fate of the working poor, who face a very different labor market than that of 30 or 60 years ago, is very important in view of the Reagan "safety net" approach and the fact that they do not share all the same interests, benefits, or supports as either the welfare-dependent poor or the middle class.

O'Connell said that entering the sociological perspective would reveal many tensions in the institutions of the urban-industrial era. Personal relationships can be deeper and quantitatively greater, but there are also depersonalizing tendencies. The amount of independence is tied to the amount of interdependence. There are new kinds of freedom and new risks. Divorce rates are up as satisfaction levels in intact marrages are increasing. Religion often provides vision and motivation to lift people out of their poverty, but it also legitimates inequities.

As part of the preparation for the bishops' pastoral on the economy, theologians might ask which of the following five ideas of a just world are supported by current religious ideas and images: (1) injustice is built into the nature of things; (2) problems are caused by the perversity or laziness of individuals, not by structures; (3) the present system has helped many lead fuller lives, but it also contains inequities - change must be gradual lest previous gains be lost; (4) the basic system is just, but components have to be changed to adapt to changing circumstances; (5) the basic system is unjust, and must be replaced.

Kathy E. Ferguson, speaking on the understanding of the social self in the writings of George Herbert Mead, said that a reconstituted view of the self as social is important for two reasons: (1) it provides grounds from which to combat the pervasive, possessive individualism in American social theory; and (2) it corrects the persistent male bias in standard individualistic views of the self and assists in creating a view of self-other relations that is more adequate for articulating women's experience and assisting in the quest for liberation. George Herbert Mead's theory of the self is useful for both of these purposes, and thus provides a starting point for further analysis.

From Mead we learn that there are two basic dimensions to the self: sociality and process. The self is fundamentally social in that it is relational, constituted out of connections with others. We become individuals by taking the perspective of particular others, and of the generalized others, onto ourselves and responding to ourselves as others respond to us. The self is also fundamentally processual in that it has no substantive structure, no object-like existence, but is rather an active, creative process. The self, in other words, is emergent; we are defined by our connections with others, but not exhausted by them, since the ability of the self to project itself toward the future and to redefine the past introduces novelty, uniqueness, and motion into personality. 
Mead's view of the self has important implications for politics. From the processual nature of the self there emerges the capacity for freedom, for defining one's own situation; from the social nature of the self there emerges the capacity for community, for nourishing our connections to others. Freedom and community are simultaneous possibilities, not mutually exclusive priorities. But Mead's view of the relation between freedom and community neglects to consider the impact that an unequal distribution of power has on political life. Once power is introduced into self-other relations, as it is in racial, sexual, economic and administrative relations, the process of self-development for those who are subordinate differs radically from that of those who are dominant. The powerful do not need to continue taking the perspective of the other onto themselves, since they are able to act without doing so; subordinates, on the other hand, must take the perspective of the other onto themselves in order to anticipate the demands of the other and to survive in a world in which they are radically dependent on those whom they do not control.

The search for liberation requires the abolition of all relations of dominance and subordinance so that the two dimensions of freedom and community can be equally available to all. The tension between the two values should rightfully be placed within all individuals, not between groups, because it is a tension rooted in the dual dimensions of the human self, sociality and process. ${ }^{1}$

Mary Buckley spoke on "A Feminist Perspective on Method in Theology." She pointed out that we know today that there is no such thing as a value-free method in any of the fields of study. Genuine scholarship is essential but the interplay between the observer, the scientist, and the field observed is always relational. The questions asked, the facts selected, always determine to a great extent, the report, the history which is recounted. Over the millenia because of the structural power frameworks of patriarchy, women have not directly contributed to the documents in any field of study. Women's experience, their way of looking at the facts, their selection of facts, has been either passed over completely or falsely construed.

A feminist perspective on method in theology challenges all the androcentric methods of the past (and present). Such a critical feminist approach has been well underway in literature and the social sciences for almost two decades. It is at work also in theology. Two recent books give it great impetus: In Memory of Her by E.S. Fiorenza and Sexism and God-Talk by R. Ruether.

A critical feminist approach or method does not mean that women's names and achievements are unearthed-and then added. A critical feminist method when pursued in depth demands a transformation. Because the voice of more than half the human race has not been heard, hearing it

1 This presentation summarizes some of the main ideas in Kathy E. Ferguson's Self, Society and Womankind: The Dialectic of Liberation (Westport, Mass: Greenwood Press, 1980). 
means that a new perspective is required at every point. For theology it means a new understanding of power, of authority; it is a direct challenge to the patriarchal-hierarchical order; and to the androcentric mode of handing on tradition.

A critical feminist approach goes by way of experience and it recognizes that women's experience has been denied, passed over, belittled, or subsumed under the experience of men. Yet women have helped to create all past history and theology. Women have been there, but their accounts have not received expression. It is men who have controlled the expression even of women's experience. One other point is important here: a critical feminist method in theology recognizes that the experience of the present is a touchstone, a point of judgment, even for the experience of the past. In this method political, cultural, economic and religious power structures which have developed in the patriarchal millenia must be perceived and criticized. That is so because the question of power in all its cultural forms has shaped the established theology.

In developing a feminist critical method we can say in summation that three basic elements are essential. 1) A criticism of what has been wrong in the androcentric traditioning process. 2) Compensation by endeavoring to unearth the possible significant contributions of women in the past so that women may not be completely "hidden from history." 3) The constructive work of envisioning a world without domination: a world of freedom and equality for women and for all who are poor, denigrated, despised and cast out. The oppression of women is paradigm for all oppression; the overcoming of such oppression is the vision of a new society, a new world.

Joseph Komonchak dealt with the social sciences and ecclesiology. $\mathrm{He}$ said that social theory is of assistance to ecclesiology in two ways. 1) Method: in virtue of the parallel between what a sociologist does in trying to understand social reality and what an ecclesiologist does in trying to understand the church. 2) Substantively: by providing categories analytical and systematic for an understanding of the church.

Komonchak outlined four areas in which social theory can assist ecclesiology. 1) The study of primitive Christianity, i.e., the community that is the social and historical effect of the ministry, death and resurrection of Jesus Christ. 2) The construction of a systematic ecclesiology: at least if this is conceived not only as a study of statements about the church but also as an understanding of the experiences and symbols; insights, concepts and words; judgments and statements, decisions and acts; relationships and institutions; through which a group of women and men become and are the People of God. 3) The study of the concrete, contemporary church, that is not the church of official or theological statements but the actual church of men and women which does not always coincide with those statements. 4) Practical theology where this is conceived as the discipline concerned with the experience of Christian responsibility for the continuing self-genesis of the church.

Paul Surlis spoke on the need for all theologians to recognize the importance of formally and explicitly contextualizing their theological 
work. He argued that the theologians of liberation have shown that all theological writing is inescapably political. Theology that seeks to evade the major public issues in the name of being a-political is, in fact, uncritically on the side of the prevailing conditions of society. The theology that is apparently contextless (it speaks of "catholic principles," or "the catholic faith") and is addressed to all people everywhere, (or it is addressed to "the human condition") is not quite as universal as it seems. Its authors are usually members of a very specific group (until recently they were white, male, affluent clerics) and this theology unselfconsciously addresses the issues the class producing it deems important. The limited nature of such theology is shown by its almost complete failure to mention the sufferings and oppressions of the poor, of women or blacks. It was only when theological reflection originated with the poor themselves, with blacks, and with women that their voices began to be heard.

The U.S. is the scene of robust black and feminist theologies. However, the issues of poverty, discrimination and oppression must become issues for all theologians writing in the U.S. if they are to make the prophetic, gospel-inspired option-for-the-poor the perspective from which they do theology. In the U.S. theology must be done with an awareness both of the global role the U.S. exercises with its many victims, especially in thirdworld countries, and of the destitute and oppressed within the U.S. itself. Third-World theologians have made us aware of the victims abroad; it is up to ourselves to take account of the victims at home. Available statistics, Surlis said, show that there are 30 million poor persons in the U.S.

Within this group the burdens of poverty fall disproportionately on women and children, especially when they are persons of color; 35 million persons are near-poor, that is one pay-check loss (by accident or serious illness) away from welfare. Upwards of 10 million (some place the number closer to 20 million) are unemployed. Studies show that stress-related disease, violence against children and women, drug-abuse, alcoholism, admission to mental institutions, crime, homicide and suicide increase as unemployment worsens. Between 2-3 million persons are currently homeless. Meanwhile the military budget increases and its projected expenditure over the next five years is five trillion dollars, the equivalent of about $\$ 3,000$ per household. Not surprisingly, in a time of massive unemployment, prison populations overflow with inmates drawn mostly from the ranks of the poorest in society. Capital punishment is making a return in many states. These and a host of unmentioned social issues form the inescapable context within which we do theology and endeavor to live as church. (It should be said that the bishops of the country have shown themselves far ahead of the theologians in addressing major social problems over the past decade). In such a context to do a universal theology or to address "the human condition" where oppressor and oppressed are equal, is to make invisible the real suffering which it should be the business of theology to identify and seek to redress.

Discussion centered around the need for all theologians to become conscious of the inter-related issues of race, class, sexism and a permanent 
war economy with its escalating arms race. The need for theologians to work collaboratively with political scientists and economists as well as sociologists and other social scientists was repeatedly stressed. Structural injustice, social sin, oppression, poverty and other forms of discrimination are not only problems for the theologies of liberation, especially the foreign ones. They are inescapable issues for all who do theology in the U.S.A. However, as the theologies of liberation have shown, the real challenge is not to do theology for the poor and the oppressed but to do theology with them in their ghettos and tenements. How to do theology also with the middle class and wealthy but from the perspective of the option-for-the-poor, who are isolated in their ghettos and tenements, is among the major challenges facing theologians as we seek to contextualize our theology in the U.S.A. so that it is politically, economically and socially responsible.

PAUL SURLIS

St. John's University

Jamaica, N.Y. 